Old Dominion University

ODU Digital Commons

Information Technology \& Decision Sciences

Faculty Publications

Information Technology \& Decision Sciences

2021

\title{
Editorial: Leveraging Emerging Technology to Fight the COVID-19 Pandemic
}

Ling Li

Old Dominion University, lli@odu.edu

Follow this and additional works at: https://digitalcommons.odu.edu/itds_facpubs

Part of the Business Administration, Management, and Operations Commons, Operations and Supply Chain Management Commons, and the Technology and Innovation Commons

\section{Original Publication Citation}

Li, L. (2021). Editorial: Leveraging emerging technology to fight the COVID-19 pandemic. Journal of Industrial Integration and Management, 6(2), 141-145. https://doi.org/10.1142/S2424862221020012

This Editorial is brought to you for free and open access by the Information Technology \& Decision Sciences at ODU Digital Commons. It has been accepted for inclusion in Information Technology \& Decision Sciences Faculty Publications by an authorized administrator of ODU Digital Commons. For more information, please contact digitalcommons@odu.edu. 
Journal of Industrial Integration and Management

Vol. 6, No. 2 (2021) 141-145

(C) World Scientific Publishing Co.

DOI: $10.1142 / \mathrm{S} 2424862221020012$

\title{
Editorial
}

\section{Leveraging Emerging Technology to Fight the COVID-19 Pandemic}

\author{
Ling $\mathrm{Li}$ \\ Department of Information Technology and Decision Science \\ Old Dominion University, Norfolk, VA 23529, USA \\ lli@odu.edu
}

Publisied 5 May 2021

The COVID-19, also known as the coronavirus pandemic, is an ongoing pandemic caused by severe acute respiratory syndrome coronavirus 2 (SARS-CoV-2). The World Health Organization declared the outbreak a Public Health Emergency of International Concern in January 2020 and a pandemic in March 2020. Coronavirus disease 2019 resulted in immense challenges that the world faces (Wei et al., 2020; $\mathrm{Xu}, 2020 \mathrm{a}$; Yin et al., 2020). COVID-19 is accelerating industrial sectors' efforts in developing emerging technologies to fight against COVID-19.

Emerging technologies are those technological innovations that represent progressive developments within a field for competitive advantage or converging technologies representing previously distinct fields that are in some way moving towards more vital interconnection. Emerging technologies include a variety of technologies such as nanotechnology (Ivanov and Muminova, 2016a, 2016b; Ivanov et al., 2020, 2021), artificial intelligence (Xu, 1999; Chi-Hsien and Nagasawa, 2019; Haenlein et al., 2019; Lu, 2019; Mazurek and Małagocka, 2019; Tung, 2019; Kang et al., 2020; Kullaya Swamy and Sarojamma, 2020; Chen et al., 2021), IoT (Xu et al., 2014, 2018; : Gorkhali et al., 2020; Lu and Ning, 2020; Pradhan and Chawla, 2020; Zhao et al., 2020 ), industrial information integration ( $\mathrm{Xu}, 2011,2020 \mathrm{~b}$ ), and many others ( $\mathrm{Li}$ et al., 2001; Li and Xu, 2001; Shi et al., 2007; Wang et al., 2007; Xu et al., 2008; Tan et al., 2010; Xu, 2013). Emerging technologies have attracted much attention from industry ( $\mathrm{Li}$ et al., 2014; Li, 2020) and have played an important role in fighting against the COVID-19.

In this aspect, there are many research issues needed to be addressed. The purpose of this special issue reports the research and practice in emerging technologies used to fight against COVID-19. The special issue also serves as a forum for scholars and practitioners to share their research results related to emerging technologies and pandemic control. 
In the paper entitled "Significant role of modern technologies for COVID-19 pandemic" by Vaishya et al. (2021), the authors have discussed the technologies that can save human lives by providing innovative solutions in fighting against COVID19 pandemic.

Nanomedicine ranges from the medical applications of nanomaterials and biological devices to nanoelectronic biosensors. Gupta et al. (2021) discussed the ap- . plication of nanotechnology in medical treatments.

Currently, biosensor technology drives much of the mobile and wearable device industry (Li et al., 2013; Chen et al., 2021). In the paper entitled "Advancements in Biosensor technologies for the medical field and COVID-19 pandemic" (Bahl et al., 2021a), authors consider biosensors technologies to play a crucial role in diagnosing various medical diseases, including COVID-19. The paper describes the significant advancement of biosensor-based technological solutions for medical diagnosis related to COVID-19.

In the paper, by Bahl et al. (2021b), entitled "Bioengineering technology in context to COVID-19 pandemic: Potential roles and applications", the authors consider that in collaboration with other disciplines, bioengineering having a wide range of important applications can play a significant role in propagating the immediate and urgent response to the COVID-19.

Cloud computing is available on-demand, including servers, storage, databases, networking, software, over the cloud (Jiang et al., 2014; Aceto et al., 2020). In the paper by Singh et al. (2021) entitled "Cloud computing in solving problems of COVID-19 pandemic", the authors have discussed leverage the function of cloud computing to fight against the COVID-19 pandemic.

Tissue engineering is a biomedical engineering discipline. In the paper entitled "Tissue Engineering and its Significance in Healthcare during COVID-19 Pandemic: Potential Applications and Perspectives" by Softa et al. (2021), the authors explored tissue engineering's useful applications during the ongoing COVID-19 pandenic situation.

Effectively managing the medical supply chain during the pandemic is a topic discussed by the media every day. In the paper co-authored by Khan et al. (2021), the authors identified and discussed the significant impact of COVID-19 on the current supply chain, with specific reference to the medical supply chain.

In the paper entitled "COVID-19 Pandemic and Debates on the Design of Operating Theatre Ventilation Systems in Healthcare Facilities", Jaly et al. (2021) have reviewed the literature related to the challenges the society faced during the COVID19 pandemic and practical operating theatre ventilation system implementation cases.

In the paper entitled "Technological Resources for fighting COVID-19 Pandemic Health Issues", Tyagi et al. (2021) concluded that the deficiency in medicines and other necessary equipment could be solved by employing engineering technology for finding specific solutions. 
We hope that this special issue will serve our readers as an avenue to gain a new perspective on emerging technologies in fighting against a pandemic. We are deeply grateful to the many individual reviewers who worked so diligently to make this special issue possible. Without their time, effort, and support, this issue would never have come to be.

\section{References}

Aceto, G, V Persico and A Pescapé (2020). Industry 4.0 and health: Internet of things, big data, and cloud computing for healthcare 4.0. Journal of Industrial Information Integration, 18, 100129.

Bahl, S, AK Bagha, S Rab, M Javaid, A Haleem and RP Singh (2021a). Advancements in biosensor technologies for medical field and COVID-19 pandemic. Journal of Industrial Integration and Management, 6(2), 175-191.

Bahl, S, KP Iyengar, AK Bagha, I Jaly, V Jain and R Vaishya (2021b). Bioengineering technölogy in context of COVID-19 pandemic: Potential roles and applications. Journal of Industrial Integration and Management, 6(2), 193-207.

Chen, X, L Gong, L Wei, SC Yeh, L Xu, L Zheng and Z Zou (2021). A wearable hand rehabilitation system with soft gloves. IEEE Transactions on Industrial Informatics, 17(2), 943-952.

Chen, H, L Li and Y Chen (2021). Explore success factors that impact artificial intelligence adoption on telecom industry in China. Journal of Management Analytics, 8(1), 36-68.

Chi-Hsien, K and S Nagasawa (2019). Applying machine learning to market analysis: Knowing your luxury consumer. Journal of Management Analytics, 6(4), 404-419.

Gorkhali, A, L Li and A Shrestha (2020): Blockchain: A literature review. Journal of Management Analytics, 7(3), 321-343.

Gupta, N, S Bahl, AK Bagha, S Vaid, M Javaid and A Haleem (2021). Nanomedicine technology and COVID-19 outbreak: Applications and challenges. Journal of Industrial Integration and Management, 6(2), 161-174.

Haenlein, M, A Kaplan, CW Tan and P Zhang (2019). Artificial intelligence (AI) and management analytics. Journal of Management Analytics, 6(4), 341-343.

Ivanov, L, L Xu, E Bokova, A Ishkov and S Muminova (2020). Nanotechnologies: A review of inventions and utility models. Part V. Nanotechnologies in Construction: A Scientific Internet-Journal, 12(6), 331-338.

Ivanov, L, L Xu, E Bokova, A Ishkov and S Muminova ،(2021). Inventions of scientists, engineers and specialists from different countries in the area of nanotechnologies. Part I. Nanotechnologies in Construction: A Scientific Internet-Journal, 13(1), 23-31.

Ivanov, L and S Muminova (2016a). Patents for inventions. Nanotechnologies in Construction: A Scientific Internet-Journal, 8(4), 93-110.

Ivanov, L and S Muminova (2016b). Patents for inventions. Nanotechnologies in Construction: A Scientific Internet-Journal, 8(5), 137-156.

Jaly, I, PK Iyengar, S Bahl, V Jain and R Vaishya (2021). COVID-19 Pandemic and Debates on the Design of Operating Theatre Ventilation Systems in Healthcare Facilities. Journal of Industrial Integration and Management, 6(2), 257-269.

Jiang, L, L Xu, H Cai, Z Jiang, F Bu and B Xu (2014). An IoT-oriented data storage framework in cloud computing platform. IEEE Transactions on Industrial Informatics, 10(2), 1443-1451.

Joshi, P, RK Tyagi and KM Agarwal (2021). Technological resources for fighting COVID-19 pandemic health issues. Journal of Industrial Integration and Management, 6(2), 271-285. 
Kang, Y, Z Cai, WC Tan, Q Huang and H Liu (2020). Natural language processing (NLP) in management research: A literature review. Journal of Management Analytics, 7(2), 139-172.

Khan, S, A Haleem, GS Deshmukh and M Javaid (2021). Exploring the impact of COVID-19 pandemic on medical supply chain disruption. Journal of Industrial Integration and Management, 6(2), 235-255.

Kullaya Swamy, A and B Sarojamma (2020). Bank transaction data modeling by optimized hybrid machine learning merged with ARIMA. Journal of Management Analytics, 7(4), 624-648.

$\mathrm{Li}, \mathrm{S}, \mathrm{S}$ Feng and XL Li (2001). Information visualization for intelligent decision support systems. Knowledge-Based Systems, 14(5-6), 259-262.

$\mathrm{Li}, \mathrm{S}, \mathrm{L} \mathrm{Xu}$ and X Wang (2013). A continuous biomedical signal acquisition system based on compressed sensing in body sensor networks. IEEE Transactions on Industrial Informatics, $9(3), 1764-1771$.

Li, L, S Li and S Zhao (2014). QoS-aware scheduling of services-oriented internet of things. IEEE Transactions on Industrial Informatics, 10(2), 1497-1505.

$\mathrm{Li}, \mathrm{H}$ and $\mathrm{L} \mathrm{Xu}$ (2001). Feature space theory - a mathematical foundation for data mining. Knowledge-based Systems, 14(5-6), 253-257.

Li, L (2020). Education supply chain in the era of Industry 4.0. Systems Research and Behavioral Science, 37(4), 579-592.

$\mathrm{Lu}, \mathrm{Y}$ and X Ning (2020). A vision of $6 \mathrm{G}-5 \mathrm{G}$ 's successor. Journal of Management Analytics, $7(3), 301-320$.

Lu, Y (2019). Artificial intelligence: A survey on evolution, models, applications and future trends. Journal of Management Analytics, 6(1), 1-29.

Mazurek, G and K Małagocka (2019). Perception of privacy and data protection in the context of the development of artificial intelligence. Journal of Management Analytics, $6(4), 344-364$.

Pradhan, K and P Chawla (2020). Medical internet of things using machine learning algorithms for lung cancer detection. Journal of Management Analytics, 7(4), 591-623.

Shi, Z, Y Huang, Q He, L Xu, S Liu, L Qin, Z. J Jia, H Li, Huang and L Zhao (2007). MSMiner - a developing platform for OLAP. Decision Support Systems, 42(4), 2016-2028.

Singh, PR, A Haleem, M Javaid, R Kataria and S Singhal (2021). Cloud computing in solving. problems of COVID-19 pandemic. Journal of Industrial Integration and Management, 6(2), 209-219.

Softa, A, S Bahl, KA Bagha, S Sehgal, A Haleem and M Javaid (2021). Tissue engineering and its significance in healthcare during COVID-19 pandemic: Potential applications and perspectives. Journal of Industrial Integration and Management, 6(2), 221-233.

- Tan, W, Y Xu, W Xu, L Xu, X Zhao, L Wang and L Fu (2010). A methodology toward manufacturing grid-based virtual enterprise operation platform. Enterprise Information Systems, 4(3), 283-309.

Tung, K (2019). AI, the internet of legal things and lawyers. Journal of Management Analytics, 6(4), 390-403:

Vaishya, R, M Javaid, HI Khan, A Vaish and PK Iyengar (2021). Significant role of modern technologies for COVID-19 pandemic. Journal of Industrial Integration and Management, $6(2), 147-159$.

Wang, C, L Xu and W Peng (2007). Conceptual design of remote monitoring and fault diagnosis systems. Information Systems, 32(7), 996-1004.

Wei, LLY, AAA Ibrahim, K Nisar, IZA Ismail and I Welch (2020). Survey on geographic visual display techniques in epidemiology: Taxonomy and characterization. Journal of Industrial Information Integration, 18, 100139. 
- Xu L, W Tan, H Zhen and W Shen (2008). An approach to enterprise process dynamic modeling supporting enterprise process evolution. Information Systems Frontiers, 10(5), 611-624.

$\mathrm{Xu}, \mathrm{L}, \mathrm{W}$ He and $\mathrm{S} \mathrm{Li} \mathrm{(2014).} \mathrm{Internet} \mathrm{of} \mathrm{things} \mathrm{in} \mathrm{industries:} \mathrm{A} \mathrm{survey.} \mathrm{IEEE} \mathrm{Transactions} \mathrm{on}$ Industrial Informatics, 10(4), 2233-2248.

$\mathrm{Xu}, \mathrm{L}, \mathrm{E} \mathrm{Xu}$ and L Li (2018). Industry 4.0: State of the art and future trends. International Journal of Production Research, 56(8), 2941-2962.

$\mathrm{Xu}, \mathrm{L}$ (1999). Artificial intelligence applications in China-Preface. Expert Systems with Applications, 16(1), 1-2.

$\mathrm{Xu}, \mathrm{L}$ (2011). Enterprise systems: State-of-the-Art and future trends. IEEE Transactions on Industrial Informatics, $7(4), 630-640$.

$\mathrm{Xu}, \mathrm{L}$ (2013). Introduction: Systems science in industrial sectors. Systems Research and Behavioral Science, 30(3), 211-213.

$\mathrm{Xu}, \mathrm{L}$ (2020a). Editorial - Industrial innovation in the intervention and prevention of COVID-19. Journal of Industrial Integration and Management, 5(4), 409-412.

$\mathrm{Xu}, \mathrm{L}(2020 \mathrm{~b})$. Industrial information integration - An emerging subject in industrialization and informatization process. Journal of Industrial Information Integration, 17, 100128.

Yin, S, N Zhang and H Dong (2020). Preventing COVID-19 from the perspective of industrial information integration: Evaluation and continuous improvement of information networks for sustainable epidemic prevention. Journal of Industrial Information Integration, 19, 100157.

Zhao, S, S Li, L Qi and L Xu (2020). Computational intelligence enabled cybersecurity for the internet of things. IEEE Transactions on Emerging Topics in Computational Intelligence, $4(5), 666-674$. 